\title{
Evaluation of Nutritive Value of Mixture of Wheatbran and Abattoir Blood (Wheatblood)
}

\author{
Aniebo A. O. , Ike I. C., Ogbuaholu E. C., Herbert N. S. \\ Department of Animal Science, Chukwuemeka Odumegwu Ojukwu University, Nigeria
}

Copyright $(2016$ by authors, all rights reserved. Authors agree that this article remains permanently open access under the terms of the Creative Commons Attribution License 4.0 International License

\begin{abstract}
A 28-day feeding trial involving two hundred and forty (240) 5 week old broilers was carried out in a completely randomized design to evaluate the growth and economic analysis of finisher broiler chicken. For this purpose, an ingredient named "wheatblood" was prepared by mixing wheat bran and abattoir blood. The test ingredient was mixed at dietary levels of $0 \% 20 \%, 25 \%$ and $30 \%$ respectively, named T1, T2, T3 and T4 where T1 served as the control. Feed and water were supplied ad libitum for 28 days the trial lasted. The parameters considered were feed intake, body weight gain, feed efficiency and cost benefit analysis. Results showed that feed intake, weight gain and feed efficiency of birds differed significantly $(\mathrm{P}<0.05)$ among treatments. However, there was no significant difference $(\mathrm{P}>0.05)$ between $\mathrm{T} 1$ and $\mathrm{T} 2$ in the 3 parameters and between T3 and T4 except in feed efficiency. Feed cost reduced with increase in wheatblood inclusion in the diets. Indeed, all wheatblood based diets were significantly $(\mathrm{P}<0.05)$ cheaper than the control, and thus, cost less to produce one kilogramme of broiler. However, there was no significant difference between $\mathrm{T} 2$ and $\mathrm{T} 3$ in cost of $\mathrm{kg}$ feed and between $\mathrm{T} 2$ and $\mathrm{T} 4$ in cost of feed per $\mathrm{kg}$ broiler which was the cheapest. Therefore, $20 \%$ inclusion of wheatblood produced best growth performance and economic gains and provided cheap and efficient utilization of abattoir blood in poultry diets. It is concluded that wheatblood inclusion in broiler finisher ration significantly reduce production cost without adverse effect on growth parameters.
\end{abstract}

Keywords Nutritive Value, Mixture, Wheat Bran, Abattoir Blood, Wheatblood, Broilers

\section{Introduction}

The problem of low protein intake can be solved by increasing the production of meat and eggs, using poultry species that have fast growth rate, large size and excellent meat quality. One of the major problems of poultry production in Nigeria is the high cost of feeds. Haq and Akhtar,[1] reported that its cost usually ranged between $65-75 \%$ of the total production cost This is also mainly due to competition between man, industries and livestock for the available feedstuffs. According to Esonu et al [2], these crippling realities that are characteristics of third world countries has led to the use of locally available, and cheap industrial by-products, novel crops and animal wastes as feed ingredients. Rao et al., [3] suggested that the possible way of increasing supply of poultry products at cheaper prices is by reducing the cost of production through the use of cheaper and locally available sources of protein such as blood meal while Aniebo et al [4] recommended maggot meal in place of costly fish meal and imported soya bean meal. Blood is one of the major by-products of livestock processing and recycling these by-products will reduce disposal and environmental pollution problems. Different methods have been used to process blood into meal for poultry feeding such as solar drying, oven drying, drum drying, flash drying, and spray drying [5], None of these methods is known to have eliminated unpalatability and other negative attributes of blood meal in moat developing countries such as Nigeria probably because ideal equipment for these methods are lacking There is therefore need to explore other ways of enhancing the nutritive value and biosafety of the abattoir blood as animal feedstuff.

Wheat bran is a by-product of dry milling of common wheat (Triticum aestivum) into flour, it is one of the major agro industrial by-products used in animal feeding. Wheat bran is the coarse outer covering of the wheat berry. Sometimes screenings are ground and added to the bran. Wheat bran contributes bulk to ruminant feeds and is a source of carbohydrates, protein, minerals and vitamins. Generally, wheat bran will have a crude protein level of 14-17 percent; crude fat, 3-4.5 percent; and crude fibre, 10.5-12 percent [6]. It is suitable for livestock feeding and very palatable to most classes of animals [7]. It consist of the outer layers (cuticle, pericarp and seed coat) combined with small amount of starchy endosperm of the wheat kernel. Javed et al. [8]) reported that milling of one million tons of wheat can yield 0.25 million tons of wheat bran. Arrajoki, [9] 
noted that the price of the wheat bran is from 70 to 140 euros per kilo, depending on its quality. Wheat bran contains many nutritionally valuable components, such as dietary fiber, proteins and phenolic compounds with antioxidative properties [8].

\section{Materials and Methods}

The experiment was carried out at the Poultry Research Unit of the Department of Animal Science, Chukwuemeka Odumegwu Ojukwu University Teaching and Research Farm, Igbariam campus, Anambra State, Nigeria.

\section{Source and processing of wheatblood}

Wheat bran was procured from Palmark Agro store, Nnobi in Idemili North LGA, while fresh cattle blood was collected with clean plastic containers from Odumodu abattoir, Umunya in Oyi LGA, of Anambra State. The wheat bran was mixed with the cattle blood at a ratio of $3: 4$ respectively and sun-dried for 4 days to $90 \%$ dry matter. The dried crumbs (test ingredient) were ground to a meal with the hammer mill and code-named "wheatblood". A sample of the processed wheatblood was analyzed to determine its crude protein, crude fibre, ether extract, dry matter, ash contents according to the methods of AOAC [10] (Table 1). The metabolizable energy (Kcal $/ \mathrm{kg})$ of wheatblood was estimated using Pauzenga [11] formula: ME $\sim 35 \mathrm{xCP} \%+81.8 \times \mathrm{EE} \%+35.5 \times \mathrm{NFE}$

Table 1. Proximate Composition of Wheatblood (\%)

\begin{tabular}{|c|c|}
\hline Nutrient & Composition \\
\hline Crude Protein & 33.48 \\
\hline Crude Fiber & 6.5 \\
\hline Fat & 1.9 \\
\hline Moisture & 12.0 \\
\hline Ash & 8.5 \\
\hline Dry Matter & 88.0 \\
\hline M. E Kcal $/ \mathrm{kg}$ & 3,085 \\
\hline
\end{tabular}

\section{Formulation of wheatblood-based experimental diets}

Four broiler finisher diets were formulated with different inclusion levels of wheatblood. The control diet (D1) contained $0 \%$ wheatblood, while diets 2,3 and 4 contained $20 \%, 25 \%$ and $30 \%$ wheatblood respectively (Table 2 ).
Table 2. Composition of Wheatblood-Based Experimental Diets Treatment

\begin{tabular}{|c|c|c|c|c|}
\hline Ingredients & $\mathrm{T}_{1}$ & $\mathrm{~T}_{2}$ & $\mathrm{~T}_{3}$ & $\mathrm{~T}_{4}$ \\
\hline Wheatblood & - & 20.0 & 25.0 & 30.0 \\
\hline Maize & 45.0 & 20.0 & 15.0 & 10.0 \\
\hline Cassava & 5.0 & 20.0 & 22.0 & 25.0 \\
\hline Soyabean meal & 26.0 & 25.0 & 23.0 & 20.0 \\
\hline Wheatbran & 8.0 & 5.0 & 5.0 & 5.0 \\
\hline Fishmeal & 5.0 & 4.6 & 4.6 & 4.6 \\
\hline Bloodmeal & 5.0 & - & - & - \\
\hline $\begin{array}{c}{ }^{*} \text { Vit/min } \\
\text { premix }\end{array}$ & 0.6 & 0.5 & 0.5 & 0.5 \\
\hline Bone meal & 3.5 & 3.0 & 3.0 & 3.0 \\
\hline Limestone & 1.0 & 1.0 & 1.0 & 1.0 \\
\hline Dl methionine & 0.2 & 0.2 & 0.2 & 0.2 \\
\hline Lysine & 0.2 & 0.2 & 0.2 & 0.2 \\
\hline Salt & 0.5 & 0.5 & 0.5 & 0.5 \\
\hline TOTAL & 100.0 & 100.0 & 100.0 & 100.0 \\
\hline Nutrient. & & & & \\
\hline Crude Protein & 22.01 & 21.76 & 21.53 & 21.77 \\
\hline M.E Kcal/kg & $2,949.6$ & $2,804.5$ & $2,875.3$ & $2,867.2$ \\
\hline
\end{tabular}

${ }^{* * *}$ Vit/min premix to provide the following per kg of diet; Vit A, 10,000iu; Vit D2, 1,500iu; Vit E, 3iu; Vit K, 2mg; Riboflavin, 3mg; Vitamin B 12, $0.08 \mathrm{mg}$; Folic acid, 4mg; Mn, 8mg; Zn, $0.5 \mathrm{mg}$; Iodine, $1.0 \mathrm{mg}$; Co, $1.2 \mathrm{mg}$; $\mathrm{Cu}, 10 \mathrm{mg} ; \mathrm{Fe} .20 \mathrm{mg}$

\section{Analysis of Data}

Data collected was subjected to statistical analysis using the procedure as described in ANOVA by Steel and Torrie (SAS, [12]). Significantly different means were separated using Duncan's New Multiple Range Test as outlined by Obi [13]

\section{Results and Discussion}

The result of the effect of experimental diets on broiler finisher (Table 3) showed that feed intake, weight gain and feed efficiency of birds within the experimental period differed significantly $(\mathrm{P}<0.05)$ among treatments. However, there was no significant difference $(\mathrm{P}>0.05)$ between $\mathrm{T} 1$ and $\mathrm{T} 2$ in the 3 parameters mentioned above and between $\mathrm{T} 3$ and T4 except in feed efficiency. Feed cost (Table 4) reduced with increase in wheatblood inclusion in the diets. Indeed, all wheatblood based diets were significantly $(\mathrm{P}<0.05)$ cheaper than the control, and thus, cost less to produce one kilogramme of broiler. However, there was no significant difference between $\mathrm{T} 2$ and $\mathrm{T} 3 \mathrm{in}$ cost of $\mathrm{kg}$ feed and cost of feed per broiler. There was also no significant difference between $\mathrm{T} 2$ and $\mathrm{T} 4 \mathrm{in}$ cost of feed per $\mathrm{kg}$ broiler which were the cheapest. 
The good performance of $15 \%$ inclusion level of wheatblood which exceeded the individual $5 \%$ wheat bran or blood meal inclusion limit recommended by NRC [14] and Feedipedia [5]) is an indication that mixture of blood and wheat bran and subsequent drying into one ingredient had a positive effect on the physiochemical characteristics of the individual ingredients. It is possible that the chemical reactions that took place before the mixture became dried could have brought out the catalytic ability of wheat bran. Cavalcanti and Behnke [15] showed that wheat bran can be utilized as a possible source of phytase which is capable of increasing growth rate and phosphorus utilization in broilers. Phytase catalyses the hydrolysis of phytic acid found in cereals and grains, thus wheat bran component which contains $2,400 \mathrm{U} / \mathrm{kg}[16]$ might have contributed to the gastro intestinal hydrolysis of phytate in the broilers.

The decreased feed intake and weight gain as test ingredient inclusion levels increased, suggests that broiler growth increased at a decreasing rate from $25 \%$ upwards. This tends to suggest that utilization of wheatblood by finisher broilers at that level declined. It could be attributed to over inclusion of either components of wheatblood since wheat bran has high fibre content $[14,17]$ or abattoir blood which has palatability, digestibility and amino acid imbalance problems. [5]. Hassan Khan and Ansari [18] had reported that diets containing more than $3 \%$ blood meal unfavorably influenced feed intake and body weight gain of broiler chickens, although NRC [14] gave maximum inclusion limit as 5\%. Furthermore, it could be attributed to texture of the diets with $25 \%$ \& $35 \%$ wheatblood inclusion levels. as the physical texture of a diet could affect the performance of birds. Therefore, as the level of wheatblood inclusion increased in the diet, the coarseness of the diet increased, due to the fibrous nature of wheatblood. This result is in line with the work of Babatunde and Hamzat [19] who reported that birds fed high fibre diets were unable to completely satisfy their energy and protein requirements.
The excellent economic gains of using test ingredient in broiler production could be attributed to the partial replacement of the more expensive maize with cheap wheatblood. The decreased feed cost per kilogram weight gain as wheatbood inclusion increased might be due to increase in wheatblood across the treatments. Aniebo et al, [20] reported that feed cost reduces with the inclusion of alternative feedstuffs. The result of this study creates a strong economic incentive for finding an alternative animal protein source for poultry feed as a direct step towards feed cost reduction and profit maximization the returns. Thus, the good performance of wheatblood is a milestone towards solving the problem of lack of efficient blood meal processing equipment in Nigeria and other developing countries which has drastically reduced the use of blood meal in poultry rations. The near zero utilization of this abattoir processing waste has actually increased its environmental nuisance value as the processors search for available space to dispose them. Therefore, $20 \%$ inclusion of wheatblood produced best growth performance and economic gains and provided cheap and efficient utilization of abattoir blood in poultry diets.

Table 3. Effects of Wheatblood on the Growth Parameters of Finisher Broiler Chicken (g) Treatments

\begin{tabular}{|c|c|c|c|c|c|}
\hline Parameters & 1 & 2 & 3 & 4 & SEM \\
\hline $\begin{array}{c}\text { Feed } \\
\text { intake/bird }\end{array}$ & $4645.67^{\mathrm{a}}$ & $4623.33^{\mathrm{a}}$ & $4785.67^{\mathrm{b}}$ & $4749^{\mathrm{b}}$ & 34.07 \\
\hline $\begin{array}{c}\text { Initial } \\
\text { weight/bird }\end{array}$ & $1183.3^{\mathrm{a}}$ & $1133.33^{\mathrm{b}}$ & $1173.33^{\mathrm{c}}$ & $1163.33^{\mathrm{c}}$ & 9.35 \\
\hline $\begin{array}{c}\text { Final } \\
\text { weight/bird }\end{array}$ & $2946.67^{\mathrm{a}}$ & $2886.67^{\mathrm{b}}$ & $2866.67^{\mathrm{b}}$ & $2786.67^{\mathrm{c}}$ & 33.79 \\
\hline $\begin{array}{c}\text { Weight } \\
\text { gain/bird }\end{array}$ & $1763.37^{\mathrm{a}}$ & $1753.34^{\mathrm{a}}$ & $1693.34^{\mathrm{b}}$ & $1623.33^{\mathrm{b}}$ & 32.0 \\
\hline $\begin{array}{c}\text { Feed } \\
\text { efficiency }\end{array}$ & $2.64^{\mathrm{c}}$ & $2.64^{\mathrm{c}}$ & $2.83^{\mathrm{b}}$ & $2.93^{\mathrm{a}}$ & 0.032 \\
\hline
\end{tabular}

a,b,c means within the same row with different superscript are significantly different $(\mathrm{P}<0.05)$

Table 4. Economic analysis of experimental diets

\begin{tabular}{|c|c|c|c|c|}
\hline \multicolumn{5}{|c|}{$\begin{array}{l}\text { Feedstuffs: Maize; Cassava; Wheatblood; Soybean; Wheatbran; Blood meal; Fish meal; } \\
\text { Cost ( }(\mathbb{k}) \text { /kg: 80; 60; 43; 172; 50; 120; } 140 \\
\text { Feedstuffs: Salt; V/M Premix; Bone meal; Limestone; Methionine; Lysine; } \\
\text { Cost }(\AA) / k g 10052040201300700\end{array}$} \\
\hline PARAMETERS & 1 & 2 & 3 & 4 \\
\hline Cost $(\AA) / k g$ Finisher & $118.43^{\mathrm{a}}$ & $108.43^{\mathrm{b}}$ & $105.47^{\mathrm{b}}$ & $94.67^{\mathrm{c}}$ \\
\hline Feed intake $(\mathrm{kg}) / \mathrm{Bird}$ & $4.65^{\mathrm{a}}$ & $4.62^{\mathrm{a}}$ & $4.79^{\mathrm{b}}$ & $4.75^{\mathrm{b}}$ \\
\hline Body Wt gain $(\mathrm{kg}) /$ Bird & $1.76^{\mathrm{a}}$ & $1.75^{\mathrm{a}}$ & $1.69^{\mathrm{b}}$ & $1.62^{\mathrm{b}}$ \\
\hline Cost of Feed(N)/Bird & $550.7^{\mathrm{a}}$ & $500.95^{\mathrm{b}}$ & $505.2^{\mathrm{b}}$ & $449.63^{\mathrm{c}}$ \\
\hline Cost of feed( ()$/ \mathrm{kg}$ body wt & $312.9^{\mathrm{a}}$ & $286.26^{\mathrm{c}}$ & $298.94 .36^{\mathrm{b}}$ & $277.58^{\mathrm{c}}$ \\
\hline Feed $\operatorname{cost}(\mathbb{N}) /$ ton & $118,428.57^{\mathrm{a}}$ & $108,433.33^{\mathrm{b}}$ & $105,466.67^{\mathrm{b}}$ & $94,666.67^{\mathrm{c}}$ \\
\hline
\end{tabular}

a,b,c means within the same row with different superscript are significantly different $(\mathrm{P}<0.05)$ 


\section{REFERENCES}

[1] Haq, A and Akhtar, M. 2004. Poultry farming higher Education commission, Islam-bad, Pakistan.

[2] Esonu, B. O; Azubuike, J. C; Udedibie, A. B. I; Emenalom, O. O; Iwuji, T. C and Odoemenam, V. 2011. Evaluation of the Nutritive Value of Mixture of Fermented Bovine Blood and Rumen Digesta for Broiler Finisher. Journal of Natural Sciences Research www.iiste.org ISSN 2224-3186 (Paper) ISSN 2225-0921 (Online) Vol.1, No.4, 2011

[3] Rao B.J, Karmar, G.SN, Patil, V.M. 2009. Utilization of different levels of blood meal in broiler feed. Indian Vet J. 86 (6): 642-643.

[4] Aniebo A.O, Erondu E.S and Owen O.J. 2009a. Replacement of fish meal with maggot meal in African catfish (Clarias gariepinus) diets. Revista Científica UDO Agrícola 9 (3), 666-671

[5] Feedipedia, 2015. Animal Feed Resources Information System - INRA CIRAD AFZ and FAO (C) 2012- 2015

[6] FAO, 1980. Food and Agricultural Organization. Ingredients for Fish Feed Manufacture in the United States. Chapter 9. (P. Raven and G. Walker). Western Farmers Association Seattle, Washington

[7] Fuller, M.F, 2004. The encyclopedia of farm animal nutrition. CABI publishing series, $606 \mathrm{pp}$.

[8] Javed, M.M, Zahoor, S, Shafaat, S, Mchmoodal, Gul A, Rasheed H, Bukhari A.I, Aftab, M.N and Ikram-UI.Haq, 2011. Wheat bran as a brown gold. nutritious value and its biotechnological applications. African J. Microbiology Research, 6 (4) pp. 724-733.

[9] Arrajoki, J., 2012. Production Manager fazer mills and mixes Ltd. Lahti, Finland: Discussion on production of wheat bran. (email) (personal communication 26 April 2012).

[10] AOAC (1990) The Official Method of Analysis, Association of Official Analytical Chemists, 15th Edition,Washington D.C.
[11] Pauzenga, U., 1985. Feeding parent stock. Zootecnica International, pp: 22-24.

[12] SAS, 2015. SAS Institute Inc., Cary, NC, USASAS/STAT® 14.1 User's Guide Introduction to Analysis of Variance Procedures

[13] Obi I. U. 2002. Statistical methods of detecting differences between treatment means and research methodology issue in laboratory field experimentation.

[14] NRC, 1994. Nutritive requirements of poultry. $9^{\text {th }}$ Rev. ed. National Academy Press, Washington DC.

[15] Calvalcanti, B.W and Behnke, C.K, 2004, Effect of Wheat Bran Phytase Subjected to different conditioning temperatures on phosphorus utilization by broiler chicks based on body weight and toe ash measurements. International Journal of Poultry science, 3(3): 215-219.

[16] Yao, J.H, Han, J.C, W.U, S.V., X.U, M., Zhong L.L, L, U, VR and Wang Y,J. 2007, supplemental wheat bran and microbial phytase could replace inorganic phosphorus in laying hen diets. Zech Journal of Animal Science, 52 (11) I $407-413$.

[17] Aduku. A O. 1993. Trophical feedstuff Analysis table. Department of animal science. ABU, Zaria - Nigeria

[18] Hassan Khan, S. and Ansari, N., 2007. Effect of different levels of blood meal on broiler performance during two phases of growth. Int. J. Poult. Sci. 6: 860-865. Internationa potato centre and International Institute of Tropical Agriculture, 1992, p55.

[19] Babatunde, B.B. and Hamat, R.A. (2005). Effect of feeding graded levels of kolanut husk meal on the performance of cockerels. Nigerian Journal of Animal Production 32 (1):61-66.

[20] Aniebo, A. O., Wekhe, S. N. and Okoli, I. C.2009b. 'Abattoir blood waste generation in Rivers State and its environmental implications in the Niger Delta', Toxicological \& Environmental Chemistry, 91: 4, 619 - 625 AOAC, 2000. Official methods of analytical chemist. $16^{\text {th }}$ Ed. Arlington V.A. 